\title{
Information Technology as a Discipline in Engineering Technology
}

\author{
C. Richard G. Helps, Barry M Lunt, Stephen R. Renshaw, \\ Brigham Young University, Provo, Utah/ \\ Shlomo Waks, Technion - I.I.T. Haifa Israel
}

\begin{abstract}
Computing in all its many forms continues to grow at a remarkable rate. A number of Electronics Engineering Technology programs have evolved into Electronics and Computer Engineering Technology to help educate students in this area. A significant number of schools are now offering or developing programs in Information Technology (IT) as a technical discipline, distinct from other computer disciplines. Some of these have seen explosive growth in student numbers.
\end{abstract}

BYU is developing a four-year degree program in Information Technology. The focus of this degree is the application of systems of computers to solving problems. The importance of various topics within the computing field to this discipline is discussed. Some topics not typically required in technical computing programs, such as communications and human computer interfacing are considered to be necessary. A selection of traditional computer topics such as programming, operating systems and networking are required but have a different emphasis from topics with the same name in other programs such as Computer Science.

There is ongoing development of accreditation guidelines for Information Technology within TAC-ABET. Issues leading to or hindering accreditation of such a degree are outlined.

A limited survey of institutions offering programs in IT developed from programs in Computer Science, (Management) Information Systems, Computer Engineering Technology and Engineering Technology helps to illustrate the growth in the professional discipline of IT. The focus and philosophy of IT, identifying its specific contribution to the field of technical computing, is expounded. The goals and objectives of the program are given.

\section{Introduction}

The general term "Information Technology" or IT encompasses the business, engineering, art, industry and science of development or application of computers for any kind of information processing. This is obviously a vast field that cannot be covered by any single academic discipline. A few of the academic disciplines that address areas within IT include Computer Science, Computer Engineering (Technology), Management Information Systems, Software Engineering and Information (Engineering) Technology". This paper will focus only on the 
development of Information Technology as a four-year discipline within the general purview of the field of Engineering Technology. Within these parameters IT can be defined as follows.

Information Technology is defined as the technical discipline that solves problems using computing resources. IT professionals from this discipline are competent to design and critically evaluate computing systems with due consideration of the performance and compatibility aspects of hardware, software and digital communication and networking. Professionals in this discipline are also proficient in understanding user needs and communicating technical issues to the organizations and people affected by the computer system. They are user's advocates. They are competent to visualize, structure and implement complex technical solutions. These professionals are "anxiously engaged" in life-long learning in order to understand and wisely use new technologies as they become available. They are broadly educated at the university level to attain both balance in their lives and depth of understanding in technology and its relevance in the broader world context. Due to the influence and leadership roles we expect such professionals to have, students are encouraged to develop high moral and ethical standards as well as being conversant with and compliant with professional performance standards. The IT discipline combines strong theoretical coursework with practical application to ensure that all three aspects of the technological educational triumvirate (Knowing, Thinking, Doing) are included.

\section{Background}

Over recent years we have noticed several trends in Electronics Engineering Technology (EET). Student interest in computing and related fields, such as networking, is growing, paralleling the growth of the Internet. Conversely interest in building electronic systems is declining, partially because kit-built systems are generally more expensive than manufactured ones and partially because it is very difficult for home builders to achieve the manufacturing quality required for successful performance using home workshops. Surface mount components and high frequencies make successful home building more and more difficult. Soldering and wire wrapping as a means of developing prototypes is declining. These techniques are being replaced by extensive theoretical design and simulation followed by automatically manufacturing a few test boards. Many systems formerly designed by EETs are now being implemented directly in silicon as single VLSI chips or closely coupled chip-sets. The development of electronic circuits is thus becoming more and more the development of VLSI circuits, a largely software and simulation oriented exercise. All these factors tend to draw students away from experimenting with electronic hardware. Software, on the other hand, can still be developed by individual experimenters and there are many real and apocryphal stories of successful computer entrepreneurs. Children and young adults play computer games and use the Internet constantly. Several of them experiment with it and desire to discover how it works. These are candidates for an IT program.

These factors have contributed to steadily declining enrollments in many EET programs and growing enrollments in computer-related programs over the last ten to fifteen years. In response to this trend many EET programs have developed Computer Engineering Technology (CET) programs. 
BYU's EET program has also experienced a decline in enrollment although our emphasis in hardware and software within EET has been a fruitful outlet for many of our graduates. Informal surveys of BYU EET graduates indicate that a high percentage $(50-60 \%)$ of EET alumni consider software to be their primary technical responsibility, frequently they are working with software that interfaces with hardware. Despite declining enrollments BYU EET graduates continue to be in high demand, possibly because of a generally declining supply of graduates combined with a buoyant technology industry.

Our desire to increase the computer content of our courses combined with the national trends in EET enrollment led us to arrange two meetings of different groups of industrial advisers in 1999 and 2000. Representatives from Intel, Novell, Lucent, Micron, IBM, Anderson Consulting, L3 Communications and others all contributed helpful criticism and thoughtful input. They indicated that there was indeed a strong need for IT technical professionals. The response in both meetings was enthusiastic. The overall feeling was that such a program was needed and that it should be technical in nature. Professionals in this field should be able to integrate different computer technologies. Several suggested that the program should include hardware and digital electronic content as well as software. Industry representatives have indicated to us that the needs for IT professionals exist and that the present needs of industry are being filled by re-training Electrical Engineering, EET and Computer Science graduates with an interest in this area. It was noted that many jobs are being filled by people with "Certification" training beyond the high school level. While these certified practitioners fill a valuable role the representatives expressed the feeling that a full four-year BS, with graduate work options is highly desirable as a basis for a leadership role in this field. Certification is essentially a fairly narrow training, as witnessed for example, by the fact that certifications expire. A life-long career requires a broader and deeper education. The mathematical and scientific content of a technical BS degree provides a good foundation for this discipline.

There are also other external and objective indicators of the need for programs of this type. The Department of Labor Bureau of Labor Statistics (BLS) ${ }^{3}$ has identified a great need for IT workers such as those described in this paper. They report that "The rapid spread of computers and information technology has generated a need for highly trained workers to design and develop new hardware and software systems and to incorporate new technologies. These workers-computer systems analysts, engineers, and scientists-include a wide range of computer-related occupations. Job tasks and occupational titles used to describe this broad category of workers evolve rapidly, reflecting new areas of specialization or changes in technology, as well as the preferences and practices of employers." and also "As computer applications continue to expand, these occupations are projected to be the fastest growing and rank among the top 20 in the number of new jobs created over the 1998-2008 period. Relevant work experience and a bachelor's degree are prerequisites for many jobs; for more complex jobs, a graduate degree is preferred." The need for Systems Analysts, which, from their description most closely matches the IT professional discussed in this paper, will be the number one growth career in the period 1998-2008. Some 577,000 new workers (an increase of 94\%) will be required in this area. ${ }^{4}$

One indicator of the need for and success of programs of this type is the explosive growth of the IT program at Rochester Institute of Technology. They started their program with a handful of 
students several years ago and now have more than one thousand undergraduate students and hundreds of graduate students.

Clearly there is a great need for IT professionals now and for the foreseeable future.

\section{BYU's EIT program}

In developing the program at BYU we considered a number of approaches. In an attempt to have students with a broad perspective we initially proposed a Bachelor of Arts in Computing. Although this might attract and develop students with a wider viewpoint and a more humanistic approach to computer users and system problems, advisory board members quickly rejected it. They made it clear that graduates with such a degree would not be recognized as having sufficient technical depth to fulfill their need.

The work done by Lidtke ${ }^{2}$ et al in "An Information Systems-Centric Curriculum '99" was also very useful in developing our thinking. Our program reflects several of the principles espoused by the report, for example, teaming, a systemic approach to thinking, interpersonal skills, problem solving techniques, practical experiences and project activities.

We feel that we have now developed a program that meets the requirements for a technical fouryear IT program. Several features of the program are as follows.

- The program should include both hardware and software. Modern computer system performance is determined by the interactions of hardware, operating systems, application packages, and network connections (which again involve hardware and software). Graduates will be able to make critical evaluations of various computer systems because they understand the underlying technology. This will become particularly important as computers continue to migrate from the desktop to fill many roles in our everyday lives with wireless and embedded devices. The term "ubiquitous computing" has been coined to describe this integration of computing devices into many aspects of our lives. Thus we want our students to be grounded in electronic fundamentals, including digital electronics and frequency spectrum principles and practices.

- Software writing and management of the software creation process, while not the primary focus of the program, is also necessary. This includes modern computer languages (structured, object oriented) and at least some introduction to discrete mathematics. This would enable students to create a certain amount of software necessary for putting together complete systems and also to interact meaningfully with professional software designers.

- Human Computer Interfacing is an essential topic. As these professionals are expected to interact extensively with users it is necessary that they be able to understand problems from a user's viewpoint. This needs to go beyond developing attractive and functional web pages, although that is also significant. It needs to address the broader question of what users think and expect when they interact with technology. Communication has always been considered an important aspect of Engineering Technology and this plays well into the need for IT professionals to be user's advocates and to expound complex technical issues lucidly for their varied audiences. 
- Networking and related topics, such as web and Internet systems, are essential for an Information Technology program. The need for IT has been inspired by the rapid worldwide adoption of the Internet. In IT the emphasis is on creating usable networking and Internet systems with a strong theoretical understanding of the system. Students will gain technical and practical experience in these topics allowing them to participate and lead in areas such as network design, network administration, web servers, and Internet systems.

- Databases are essential elements for computer usability especially in the modern internetworked topologies. The students will become competent in understanding and applying database technologies. Emphasis is placed on database architecture, building, scaling, and administration. The students will be taught the classes of problems that databases can solve, how to apply them and how to integrate them with complete systems.

- Operating systems must be understood and correctly applied. Desktop, server, midrange, and mainframe operating systems are evaluated and compared. The realms of application for these operating systems are identified. For example there are operating systems suitable for technical and non-technical users, for real-time, for embedded systems and for servers, for mainframes and for portable devices. Operating systems are studied for issues such as stability, performance, networking, security, and usability. Applications of these operating systems are explored.

- The program has a significant application orientation. Students will develop real systems based on their understanding of the principles discussed in class. Thus most classes have significant lab or project components. The senior year includes a two-semester senior project where a team of students propose, develop and present a complete, working project.

- Topics such as teamwork, project management, creativity, ethics and life-long learning are required, as is appropriate general education.

This program has been designed to be accreditable under the new TC2K outcomes-oriented accreditation guidelines from TAC ABET. TC2K requires that programs clearly identify their objectives and indicate how the outcomes will be measured. Finally that measurement must feed back into the curriculum process as part of a continuous improvement process. We have developed a mission statement and defined outcomes for the program and identified how each course contributes to the program outcomes. We have also defined how outcomes will be assessed. The mission statement and objectives are included in Appendix A. The contribution of each course to the outcomes is available on the BYU EIT website. The address of the website is also available from appendix A.

The program of study is shown in the attached four-year study flowchart, Appendix B. In examining this flowchart it should be noted that all courses taught in the major have a significant application component (labs, projects etc.). This application component consists of a mixture of formal scientific style lab assignments as well as design and exploratory projects requiring several hours each week. The program culminates in a two-course sequence where the students conceive, justify, design and build a complete working system. This senior project experience is based on the highly successful senior project already being done by existing EET students. The technical report for this project is written to honors thesis standards and thus not only provides 
students an opportunity to exercise their written communication skills but also to graduate with honors if they choose.

The combination of hardware, software, electronics, applications, communication and strong technical understanding makes Engineering Technology an excellent base from which to develop IT programs.

\section{Second discipline emphasis}

We anticipate that many of the graduates from this program will find careers in areas that are not focused on IT but on some other field that uses IT extensively, such as business, computer graphics, engineering or manufacturing. In order to be most effective students should be conversant with one or more of these areas as well as with their primary academic discipline of IT. The BYU program is designed to allow students to pursue a minor in a supporting or complementary field to adapt the program to their individual needs. Several second discipline tracks are available for students to select from or they can pursue a minor of their own choosing.

As computers permeate more aspects of our society it is hoped that students from disparate majors such as Arts, Business, Education, Human Performance and the pure sciences, might choose to dual-major or minor in IT. In so doing they will have the opportunity to ensure that computer use in those fields truly serves the intended audience and provides additional capability, understanding and convenience rather than more complexity.

\section{Other Similar Programs Currently being offered in the USA}

There are a number of similar programs already developed at other institutions that appear to be close the goals and definition of IT that we have discussed. We identified a number of these programs using the Internet. The list of IT programs can be found in Appendix C.

We did some analysis of each institution to identify their offerings of some of the core topics in the IT discipline. This was not easy to do. For example, it is not always easy to determine from web pages which courses have required laboratory work and if they do have laboratory work how extensive it is. We tried to identify what programs topics were required, such as computer networking, hardware, databases, operating systems or business courses. We used this analysis to eliminate from the list those programs that are focused on software algorithm design (such as CS programs) or on computer hardware development (CE and CET programs) or primarily on business topics (MIS programs). Although many of the programs in the list may include required courses in these topics the programs were not focused on them. Rather the focus seemed to be on applications of computer systems to solving problems.

There were several noteworthy trends gleaned from the Internet survey. Some of these programs are experiencing considerable success. The growth of the RIT program was mentioned earlier. Several other programs also have hundreds of students. It was also noted that these programs have grown from different disciplines, including: CS, Engineering, Business, and Engineering Technology. Many of these programs are new and have variations in their emphasis, usually based on the discipline from which they grew. The program at BYU, for 
example emphasizes communication and teamwork in anticipation of future leadership opportunities and also requires a course in digital electronic fundamentals. Despite these variations the career placement objectives for all these programs were strikingly similar.

\section{Accreditation Issues}

Efforts are underway to develop accreditation standards through TAC of ABET and the IEEE for programs of this type. Criteria for accreditation compliant with the new outcomes oriented TAC of ABET criteria (TC2K) have been proposed through IEEE and CTAA committees and are being developed further. In general, as noted above, TAC and the ET community are a good basis for this program. Some issues need to be dealt with. For example, the TAC criteria require that four-year graduates be proficient in Calculus. While fully accepting the need for graduates to be capable of advanced mathematical reasoning, many in the IT discipline feel that an appropriate course in discrete mathematics would be of more use to IT graduates. These and other questions continue to be debated as the proposed criteria move toward adoption.

It is also noted that some conferences and publications supported by professional societies such as IEEE already exist to provide a scholarly focus for the program.

\section{Conclusions}

We feel that the time has come for the establishment of four-year IT programs as described. With the growth of computing applications there is a need for technical professionals whose educational requirements are different from those offered by traditional academic computer disciplines. Technical competency combined with analytical skills, communication skills, and an application orientation will provide leaders for the next wave of IT integration in society. This fits well into the domain of engineering technology. Students and employers alike are seeking programs of this type. The opportunities exist and are rapidly growing for life-long careers within the field. We support further development of programs in this area.

\section{Appendices}

Appendix A. Mission and Objectives of the EIT Program at BYU

Mission Statement: Electronics and Information Technology

Within the context of the Aims of a BYU Education (see ref 1) our mission is to educate professional leaders with an in-depth understanding of all aspects of computer systems and their relationship to the world. These leaders will combine their technical understanding with their broad based general education to visualize systems, communicate effectively, think analytically and implement solutions.

\section{Objectives of the EIT Program}

A graduate from the Electronics and Information Technology Program will have the characteristics listed below:

1. An in-depth understanding and experience with computer systems based on knowledge of electronics with an emphasis in digital electronics.

2. Creative and analytical thinking skills that provide a basis for technological problem solving.

3. The ability to integrate people with disparate systems including computers, communications, and other technologies

4. The ability to lead and to communicate effectively, both orally and in writing

5. The skills and attitudes of life-long learning 
6. The ability to apply knowledge, manage projects and work effectively in diverse teams.

7. The understanding of the impact of technology on society from a broad educational base and moral principles of conduct.

The BYU EIT website, http://www.eet.byu.edu/eit., contains a detailed explanation of how each of these objectives is interpreted and also how each objective will be assessed.

\section{Appendix B. Flow-Chart of four-year EIT Program at BYU}

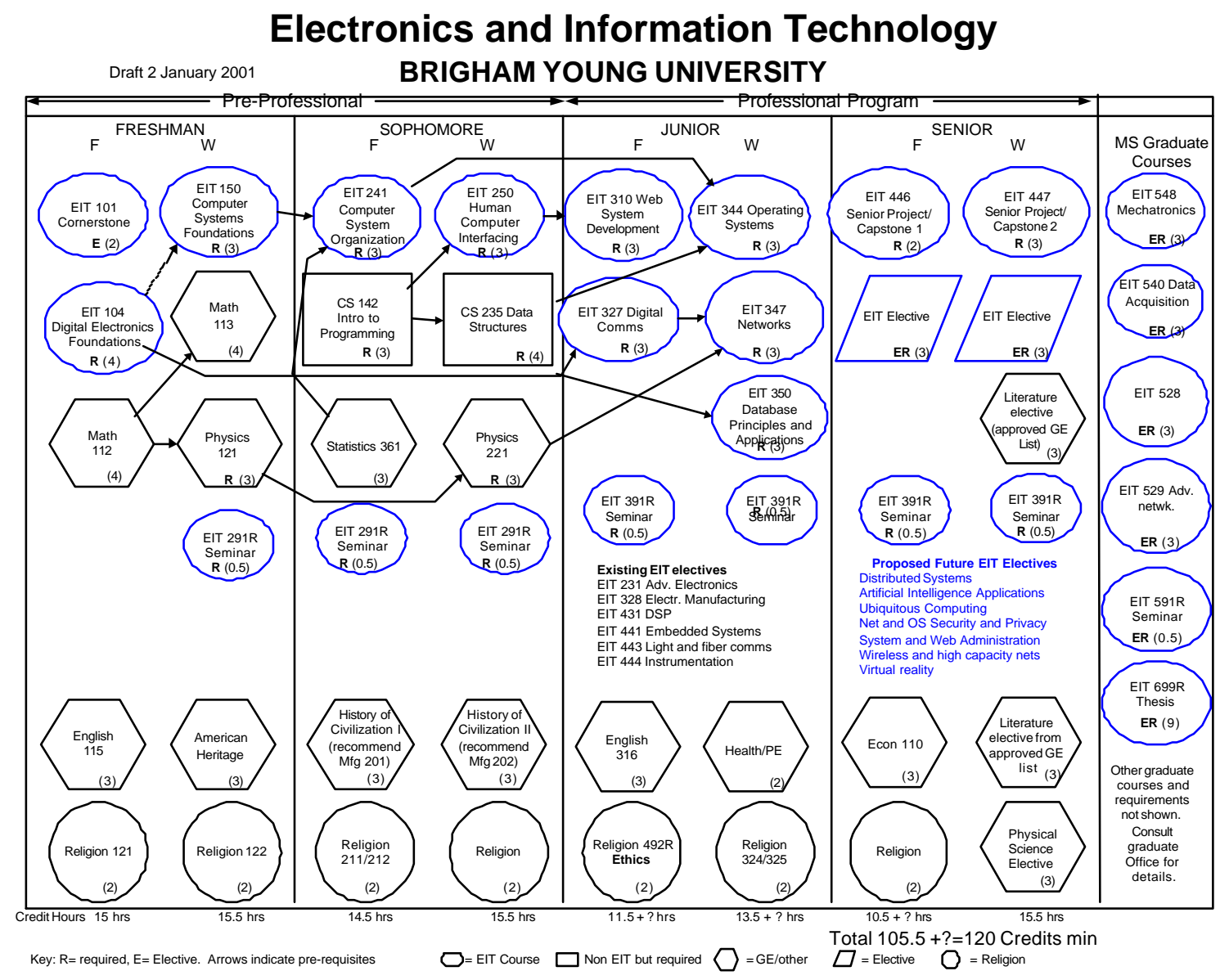

Proceedings of the 2001 American Society for Engineering Education Annual Conference \& Exposition

Copyright $\odot$ 2001, American Society for Engineering Education 
Appendix C. Institutions offering four-year IT degrees that are technical in approach

\begin{tabular}{|c|c|c|c|c|}
\hline $\begin{array}{l}\text { School or } \\
\text { University }\end{array}$ & College & Department & Program & $\begin{array}{l}\text { Website / } \\
\text { Program Characteristics* / } \quad \text { Classification* }\end{array}$ \\
\hline $\begin{array}{l}\text { Brigham } \\
\text { Young } \\
\text { University }\end{array}$ & $\begin{array}{l}\text { Engineering } \\
\text { and } \\
\text { Technology }\end{array}$ & $\begin{array}{l}\text { School of } \\
\text { Technology }\end{array}$ & $\begin{array}{l}\text { Electronics and } \\
\text { Information } \\
\text { Technology }\end{array}$ & $\begin{array}{l}\text { www.et.byu.edu/eit } \\
\text { D,E,F,H,N,O,P,S,W }\end{array}$ \\
\hline $\begin{array}{l}\text { Rochester } \\
\text { Institute of } \\
\text { Technology }\end{array}$ & & $\begin{array}{l}\text { Information } \\
\text { Technology }\end{array}$ & $\begin{array}{l}\text { BS Information } \\
\text { Technology }\end{array}$ & $\begin{array}{l}\text { www.it.rit.edu } \\
\text { D,F,N,O,P,S,W (elective) H }\end{array}$ \\
\hline $\begin{array}{l}\text { Northwestern } \\
\text { University }\end{array}$ & $\begin{array}{l}\text { McCormick } \\
\text { School of } \\
\text { Engineering } \\
\text { and Applied } \\
\text { Science }\end{array}$ & $\begin{array}{l}\text { Computer } \\
\text { Science }\end{array}$ & $\begin{array}{l}\text { BA Computing } \\
\text { and Information } \\
\text { Systems }\end{array}$ & $\begin{array}{l}\text { www.cs.northwestern.edu/curriculum/cis.html } \\
\text { D,N,O,P,S (elective) E,H }\end{array}$ \\
\hline $\begin{array}{l}\text { George } \\
\text { Mason } \\
\text { University }\end{array}$ & $\begin{array}{l}\text { School of } \\
\text { Information } \\
\text { Technology } \\
\text { and } \\
\text { Engineering }\end{array}$ & & $\begin{array}{l}\text { BS Systems } \\
\text { Engineering }\end{array}$ & $\begin{array}{l}\text { ite.gmu.edu/nj-pages/nj-departments.html } \\
\text { D,F,H,O,P,S (telecommunications track) E,H,N }\end{array}$ \\
\hline $\begin{array}{l}\text { Washington } \\
\text { University }\end{array}$ & $\begin{array}{l}\text { School of } \\
\text { Engineering } \\
\text { and Applied } \\
\text { Sciences } \\
\end{array}$ & & $\begin{array}{l}\text { BS Information } \\
\text { Management }\end{array}$ & $\begin{array}{l}\underline{\text { seas.wustl.edu/academicprograms/continuinged/BSInfoMgmt.h }} \\
\underline{\mathrm{tm}} \\
\mathrm{B}, \mathrm{D}, \mathrm{N}, \mathrm{O}, \mathrm{P}, \mathrm{S}\end{array}$ \\
\hline $\begin{array}{l}\text { Penn State } \\
\text { Berks- } \\
\text { Lehigh } \\
\text { Valley } \\
\text { College }\end{array}$ & $\begin{array}{l}\text { Division of } \\
\text { Engineering, } \\
\text { Business, } \\
\text { Computing, } \\
\text { and Human } \\
\text { Development }\end{array}$ & & $\begin{array}{l}\text { BS Computing } \\
\text { Technology and } \\
\text { Science }\end{array}$ & www.lv.psu.edu/oji/ebchd/programs/bscts/bscts.html \\
\hline $\begin{array}{l}\text { Purdue } \\
\text { University }\end{array}$ & $\begin{array}{l}\text { School of } \\
\text { Technology }\end{array}$ & $\begin{array}{l}\text { Computer } \\
\text { Technology }\end{array}$ & $\begin{array}{l}\text { BS Computer } \\
\text { Information } \\
\text { Systems } \\
\text { Technology; } \\
\text { Telecommunicati } \\
\text { ons and } \\
\text { Networking } \\
\text { Technology } \\
\text { Option }\end{array}$ & $\begin{array}{l}\text { ecn.purdue.edu/ECN/Course.catalogs/Technology/CT NET.ws } \\
\underline{\text { html }} \\
\begin{array}{ll}\text { D,N,P,S } & \text { /E }\end{array}\end{array}$ \\
\hline $\begin{array}{l}\text { Pace } \\
\text { University }\end{array}$ & $\begin{array}{l}\text { School of } \\
\text { Computer } \\
\text { Science and } \\
\text { Information } \\
\text { Systems }\end{array}$ & $\begin{array}{l}\text { Technology } \\
\text { Systems }\end{array}$ & $\begin{array}{l}\text { BS Technology } \\
\text { Systems }\end{array}$ & www.wol.pace.edu/csis/dg.html\#is \\
\hline $\begin{array}{l}\text { American } \\
\text { University }\end{array}$ & $\begin{array}{l}\text { College of } \\
\text { Arts and } \\
\text { Sciences }\end{array}$ & $\begin{array}{l}\text { Computer } \\
\text { Science }\end{array}$ & $\begin{array}{l}\text { BS Information } \\
\text { Systems }\end{array}$ & $\begin{array}{l}\text { www.csis.american.edu/programs/index.htm } \\
\text { B,D,F,H,P (elective) N,O,W }\end{array}$ \\
\hline $\begin{array}{l}\text { Drexel } \\
\text { University }\end{array}$ & $\begin{array}{l}\text { Information } \\
\text { Science and } \\
\text { Technology }\end{array}$ & & $\begin{array}{l}\text { BS Information } \\
\text { Systems }\end{array}$ & $\begin{array}{l}\text { www.cis.drexel.edu/undergrad/index.html } \\
\text { D,F,N,P,S,W }\end{array}$ \\
\hline $\begin{array}{l}\text { Griffith } \\
\text { University }\end{array}$ & $\begin{array}{l}\text { School of } \\
\text { Engineering } \\
\text { and } \\
\text { Information } \\
\text { Technology }\end{array}$ & $\begin{array}{l}\text { Computing } \\
\text { and } \\
\text { Information } \\
\text { Technology }\end{array}$ & $\begin{array}{l}\text { BS Information } \\
\text { Technology }\end{array}$ & www.gu.edu.au/ua/aa/hbk/fsscisub4.html \\
\hline $\begin{array}{l}\text { University of } \\
\text { Nebraska at } \\
\text { Omaha }\end{array}$ & $\begin{array}{l}\text { College of } \\
\text { Information } \\
\text { Science and } \\
\text { Technology }\end{array}$ & $\begin{array}{l}\text { Information } \\
\text { Systems and } \\
\text { Quantitative } \\
\text { Analysis }\end{array}$ & $\begin{array}{l}\text { BS Information } \\
\text { Systems/ } \\
\text { Quantitative } \\
\text { Analysis }\end{array}$ & $\begin{array}{l}\text { www.ist.unomaha.edu } \\
\text { D,N,O,P,S }\end{array}$ \\
\hline $\begin{array}{l}\text { Capella } \\
\text { University }\end{array}$ & $\begin{array}{l}\text { Information } \\
\text { Technology }\end{array}$ & & $\begin{array}{l}\text { BS Information } \\
\text { Technology }\end{array}$ & www.capellauniversity.edu/prgms/ugrad/index.cfm \\
\hline
\end{tabular}




\begin{tabular}{|c|c|c|c|c|}
\hline & & & & $\mathrm{B}, \mathrm{D}, \mathrm{F}, \mathrm{N}, \mathrm{P}, \mathrm{S}, \mathrm{W}$ \\
\hline $\begin{array}{l}\text { American } \\
\text { Global } \\
\text { University }\end{array}$ & $\begin{array}{l}\text { College of } \\
\text { Computer } \\
\text { Science and } \\
\text { Information } \\
\text { Technology }\end{array}$ & $\begin{array}{l}\text { Information } \\
\text { Technology } \\
\text { and Software } \\
\text { Engineering }\end{array}$ & $\begin{array}{l}\text { BS Information } \\
\text { Technology and } \\
\text { Computer } \\
\text { Science }\end{array}$ & $\begin{array}{l}\text { www.americanglobalu.edu } \\
\text { N,P,S } \quad \text { (elective) D,H }\end{array}$ \\
\hline $\begin{array}{l}\text { Oregon } \\
\text { Institute of } \\
\text { Technology }\end{array}$ & $\begin{array}{l}\text { School of } \\
\text { Engineering } \\
\text { Technology } \\
\text { and } \\
\text { Management }\end{array}$ & $\begin{array}{l}\text { Computer } \\
\text { Engineering } \\
\text { Technology }\end{array}$ & $\begin{array}{l}\text { BS Information } \\
\text { Technology }\end{array}$ & $\begin{array}{l}\text { www.oit.edu/ } \\
\text { B,D,H,N,P }\end{array}$ \\
\hline $\begin{array}{l}\text { New Jersey } \\
\text { Institute of } \\
\text { Technology }\end{array}$ & $\begin{array}{l}\text { Engineering } \\
\text { Technology, } \\
\text { Information } \\
\text { Technology }\end{array}$ & & $\begin{array}{l}\text { BS Information } \\
\text { Technology; } \\
\text { Engineering } \\
\text { Technology } \\
\text { Computer Tech } \\
\text { option } \\
\end{array}$ & $\begin{array}{l}\frac{\text { www.njit.edu }}{\text { http://it.njit.edu/bsit2.htm }} \\
\text { D,N,P,S (various concentrations) B,E,F,H,O,W }\end{array}$ \\
\hline $\begin{array}{l}\text { University of } \\
\text { Maryland } \\
\text { University } \\
\text { College }\end{array}$ & $\begin{array}{l}\text { Computer and } \\
\text { Mathematical } \\
\text { Sciences }\end{array}$ & & $\begin{array}{l}\text { BS computer \& } \\
\text { Information } \\
\text { Science }\end{array}$ & $\begin{array}{l}\text { www.marylandonline.org } \\
\text { D,N,P,S }\end{array}$ \\
\hline $\begin{array}{l}\text { Pennsylvania } \\
\text { College of } \\
\text { Technology }\end{array}$ & $\begin{array}{l}\text { School of } \\
\text { Business and } \\
\text { Computer } \\
\text { Technology }\end{array}$ & & $\begin{array}{l}\text { BS Computer } \\
\text { Information } \\
\text { Technology: Data } \\
\text { Communication } \\
\text { Networking }\end{array}$ & $\begin{array}{l}\text { http://www2.pct.edu/schools/ } \\
\text { B,N,O,P,H }\end{array}$ \\
\hline $\begin{array}{l}\text { Saint } \\
\text { Thomas } \\
\text { University }\end{array}$ & & $\begin{array}{l}\text { Physical } \\
\text { Sciences and } \\
\text { Mathematics }\end{array}$ & $\begin{array}{l}\text { BA Computer } \\
\text { Information } \\
\text { Systems }\end{array}$ & $\begin{array}{l}\text { www.stu.edu/mathsci/MSPROGRA.htm\#cis } \\
\text { D,N,O,P,S }\end{array}$ \\
\hline $\begin{array}{l}\text { Marist } \\
\text { College }\end{array}$ & $\begin{array}{l}\text { School of } \\
\text { Computer } \\
\text { Science and } \\
\text { Mathematics }\end{array}$ & $\begin{array}{l}\text { Computer } \\
\text { Science and } \\
\text { Information } \\
\text { Systems }\end{array}$ & $\begin{array}{l}\text { BS Information } \\
\text { Technology }\end{array}$ & $\begin{array}{l}\text { www.marist.edu/compscimath/it.html } \\
\text { D,H,N,P,S (Computer Technology concentration) E }\end{array}$ \\
\hline $\begin{array}{l}\text { University of } \\
\text { Central } \\
\text { Florida }\end{array}$ & $\begin{array}{l}\text { College of } \\
\text { Engineering } \\
\text { and Computer } \\
\text { Science }\end{array}$ & $\begin{array}{l}\text { Engineering } \\
\text { Technology }\end{array}$ & $\begin{array}{l}\text { BS Information } \\
\text { Systems } \\
\text { Technology }\end{array}$ & $\begin{array}{l}\text { www.ucf.edu/catalog/current/Degree Programs/information sy } \\
\text { stems tech.html } \\
\text { D,E,H,N,O,P,S } \quad \text { /I } \quad \text { (Associate Degree Required) }\end{array}$ \\
\hline $\begin{array}{l}\text { University of } \\
\text { Cincinnati }\end{array}$ & $\begin{array}{l}\text { College of } \\
\text { Applied } \\
\text { Science }\end{array}$ & $\begin{array}{l}\text { Mathematics, } \\
\text { Physics, and } \\
\text { Computing } \\
\text { Technology }\end{array}$ & $\begin{array}{l}\text { BS Information } \\
\text { Engineering } \\
\text { Technology }\end{array}$ & $\begin{array}{l}\text { www.uc.edu/cas/ } \\
\text { D,N,O,P,S,W }\end{array}$ \\
\hline $\begin{array}{l}\text { Georgia } \\
\text { Southern } \\
\text { University }\end{array}$ & $\begin{array}{l}\text { School of } \\
\text { Information } \\
\text { Technology }\end{array}$ & & $\begin{array}{l}\text { BS Information } \\
\text { Technology }\end{array}$ & $\begin{array}{l}\text { www2.gasou.edu/coba/depts./sit/index.html } \\
\text { D,H,N,P,S,W } \quad \text { (specialization) B }\end{array}$ \\
\hline $\begin{array}{l}\text { Rensselaer } \\
\text { Polytechnic } \\
\text { Institute }\end{array}$ & & $\begin{array}{l}\text { Information } \\
\text { Technology }\end{array}$ & $\begin{array}{l}\text { BS Information } \\
\text { Technology }\end{array}$ & $\begin{array}{l}\text { www.it.rpi.edu } \\
\text { D,F,H,N,O,S }\end{array}$ \\
\hline $\begin{array}{l}\text { Syracuse } \\
\text { University }\end{array}$ & $\begin{array}{l}\text { School of } \\
\text { Information } \\
\text { Studies }\end{array}$ & & $\begin{array}{l}\text { BS Information } \\
\text { Management and } \\
\text { Technology }\end{array}$ & $\begin{array}{l}\text { istweb.syr.edu/academic/programs/bs.shtml } \\
\text { B,D,N,P,S }\end{array}$ \\
\hline
\end{tabular}

* Program characteristics key:

$$
\begin{array}{ll}
\mathrm{B}=\text { Business } & \mathrm{N}=\text { Data Communications } / \text { Networking } \\
\mathrm{D}=\text { Database } & \mathrm{O}=\text { Operating Systems } \\
\mathrm{E}=\text { Electronics } & \mathrm{P}=\text { Programming } \\
\mathrm{F}=\text { Human Factors } & \mathrm{S}=\text { Other Software } \\
\mathrm{H}=\text { Computer Hardware Architecture } & \mathrm{W}=\mathrm{Web} / \text { Internet Systems }
\end{array}
$$

* Classification refers to Doctoral/Research listing in Chronicle of Higher Ed. Aug 11, 2000; E=Extensive, I=Intensive 


\section{Bibliography}

1. BYU, "The Aims of a BYU Education" http://advance.byu.edu/aims.html August 1996.

2. Lidtke, Doris K, Stokes, Gordon E., Haines Jimmie and Mulder Michael C (editors). An Information SystemsCentric Curriculum '99 National Science Foundation, July 1999. Available on-line at http://www.iscc.unomaha.edu

3. US Dept. Of Labor, Bureau of Labor Statistics, Computer Systems Analysts, Engineers, and Scientists Page http://stats.bls.gov/oco/ocos042.htm. Occupational Outlook Handbook, 2000-2001 Edition. May 2000. The complete handbook is available at http://stats.bls.gov/ocohome.htm

4. US Dept. Of Labor, Bureau of Labor Statistics, Computer Systems Analysts, Engineers, and Scientists Page http://stats.bls.gov/news.release/ooh.t02.htm. Occupational Outlook Handbook, 2000-2001 Edition. May 2000. The complete handbook is available at http://stats.bls.gov/ocohome.htm

\section{RICHARD G. HELPS}

Richard Helps is the Program Chair of the Electronics Engineering Technology program at BYU. He is also a TACABET program evaluator and vice-president of the ECET Department Heads Association. He spent ten years in industry as a control systems design engineer. He completed BS and MS degrees at the $\mathrm{U}$ of the Witwatersrand, South Africa and a further graduate degree at the University of Utah in Electrical Engineering. His primary interests are in embedded and real-time computing with its instrumentation and control aspects, combined with artificial intelligence techniques such as neural networks and fuzzy logic.

\section{BARRY LUNT}

Barry M. Lunt is an Associate Professor of Electronics Engineering Technology at Brigham Young University in Provo, UT. Dr. Lunt received a B.S. and an M.S. degree in Electronics Engineering Technology from Brigham Young University in 1978 and 1979, and a Ph.D. in Occupational and Adult Education from Utah State University in Logan, UT, in 1993. His present research emphasis is in the physical design of electronic circuits and systems, and in engineering education.

\section{STEPHEN RENSHAW}

Stephen R. Renshaw is an Instructor of Electronics and Information Technology at Brigham Young University in Provo, UT. He received a B.S. and an M.S. in Computer Science from Brigham Young University in 1985 and 1987. Prior to instructing full time he worked in various Information Technology areas including: telephony, process control, system integration, networking, and health care computing. Current research interests include: system integration and networking, and active (hands on) learning applied to technology.

\section{SHLOMO WAKS}

Shlomo Waks is an Associate Professor in the Department of Education in Technology and Science at the Technion, Haifa, Israel. He gained BSc. (1962) and M.Sc. (1973) degrees in electrical engineering, and also has an M.Sc. in science education and a Ph.D. (1973) in curriculum design (Technion and MSU). Dr. Waks has worked on international and national technology and education planning, implementation and evaluation as well as human resources development and updating in high-tech industries. He has published 58 scientific papers, 15 research reports, and 48 textbooks in technology and a scientific book on curriculum design. He has recently completed a year as a visiting professor at BYU. 